\title{
Strategi Kreatif Produser Dalam Mempertahankan Eksistensi Program Mission X Trans TV
}

\author{
Murtiadi \\ Universitas Bina Sarana Informatika, murtiadi.mdi@bsi.ac.id
}

\begin{abstract}
ABSTRAK
Mission X merupakan salah satu program game show yang ditayangkan oleh TRANS TV, tantangan bagi Produser yaitu penonton atau masyarakat yang kian hari semakin cerdas dalam memilih sebuah tayangan. Hal ini menarik peneliti untuk mengetahui bagaimana strategi kreatif produser dalam mempertahankan eksistensi program Mission X pada stasiun televisi TRANS TV. Tujuan penelitian ini untuk mengetahui bagaimana strategi kreatif produser dalam mempertahankan eksistensi program Mission X pada stasiun televisi TRANS TV. Metode yang digunakan dalam penelitian ini adalah metode deskriptif kualitatif dengan teknik pengumpulan data melalui observasi, wawancara, dan penelusuran dokumen dan diakhiri dengan analisis. Hasil penelitian yang diperoleh yaitu bagi Produser dan tim, komunikasi merupakan hal yang mempengaruhi keberhasilan dalam tim. Seorang Produser dalam menentukan strategi kreatif program Mission X berlandaskan pada elemen-elemen sebagai berikut: target penonton, bahasa naskah, format acara, punching line, gimmick and funfare, clip hanger, time and bumper, penata artistik, music and fashion, ritme dan birama acara, andago dan music track untuk ID tune, general rehearsel (GR), dan interactive program. Eksistensi program Mission X dapat bertahan dikarenakan adanya strategi kreatif yang selalu berinovasi dan komunikasi yang sudah terjalin dengan baik.
\end{abstract}

Kata Kunci: Strategi Kreatif, Produser, Eksistensi Program

\section{ABSTRACT}

Office of Religious Affairs as the spearhead of the Ministry of Religious in serving the Mission $X$ is one of the game show programs aired by TRANS TV, a challenge for Producers is the audience or the public who are increasingly smart in choosing a show. This attracts researchers to find out how the creative strategies of producers in maintaining the existence of the Mission X program on the television station TRANS TV. The purpose of this study is to find out how the creative strategy of producers in maintaining the existence of the Mission X program on the television station TRANS TV. The method used in this research is descriptive qualitative method with data collection techniques through observation, interviews, and document tracking and ending with analysis. The results of the research obtained are for Producers and teams, communication is something that affects success in the team. A Producer in determining the creative strategy of the Mission X program is based on the folandawing elements: target audience, script language, program format, punching line, gimmick and funfare, clip hanger, time and bumper, artistic stylist, music and fashion, rhythm and mood events, andagos and music tracks for ID tune, general rehearse (GR), and interactive programs. The existence of the Mission X program can survive due to the existence of creative strategies that always innovate and communication that has been well established.

Keywords: Creative Strategy, Producer, Programme Extension

ISSN: 2355-0287, E-ISSN: 2549-3299

http://ejournal.bsi.ac.id/ejurnal/index.php/jika 


\section{PENDAHULUAN}

Pada hakikatnya setiap manusia membutuhkan sebuah hiburan. Hiburan yang dibutuhkan tentunya untuk mengurangi kepenatan atau melepas lelah dari rutinitas sehari-hari. Adapun hiburan yang dapat dinikmati yaitu mulai dari berekreasi ke tempat hiburan, berkumpul bersama keluarga atau teman, dan hiburan yang paling mudah dilakukan yaitu menikmati sebuah tayangan televisi (TV).

Televisi merupakan salah satu media massa yang hampir dimiliki oleh seluruh masyarakat. Televisi merupakan sebuah media yang mampu memberikan sajian audio dan visual. Keunggulan televisi dari media lainnya salah satunya yaitu televisi memiliki siaran atau program yang dapat dipilih sesuka hati oleh pengguna televisi dan stasiun televisi dapat menanyangkan berbagai macam hiburan yang dapat dinikmati oleh semua kalangan. Televisi juga merupakan salah satu media komunikasi massa.

Program yang ditayangkan di televisi, terbagi dalam beberapa jenis, yaitu variety show, reality show, talk show dan game show. Salah satu program yang diminati oleh masyarakat saat ini adalah program game show. Game show adalah suatu program yang didalamnya berisi serangkaian permainan yang mengadu kemampuan, ketangkasan, dan kesabaran setiap peserta demi mendapatkan hadiah maupun kemenangan bagi setiap pesertanya. Salah satu stasiun televisi yang menayangkan program game show adalah TRANS TV. TRANS TV merupakan salah satu stasiun televisi yang memiliki berbagai jenis program yang banyak diminati masyarakat. Hal ini terbukti dari eksistensi TRANS TV selama kurang lebih 17 tahun mengudara dan mampu bersaing dengan stasiun televisi lainnya. Keberhasilan TRANS TV tak luput dari keberadaan Sumber Daya Manusia (SDM) dan sarana yang mendukung.

Produser merupakan salah satu SDM yang memiliki peran penting dalam pencapaian keberhasilan program TRANS TV. Tugas Produser tak hanya sekedar membuat sebuah program $\mathrm{TV}$, namun Produser juga harus mampu menciptakan ide kreatif agar program yang dijalankannya dapat bertahan dan bersaing dengan program TV lainnya. Oleh sebab itu Produser harus mampu bertanggung jawab mengeandala sebuah program dengan baik sejak awal produksi sampai program berakhir. Mission X merupakan salah satu program game show yang ditayangkan oleh TRANS TV. Program Mission X berisi serangkaian permainan yang menghibur. Dimainkan oleh dua keandampok yang terdiri dari beberapa orang yang menjalankan sebuah misi/target untuk mencapai kemenangan. Program ini dapat disaksikan oleh berbagai lapisan masyarakat mulai dari anak-anak, remaja, hingga dewasa. Program Mission X dikemas secara ringan karena program tersebut berisi konten yang menghibur.

Saat ini program Mission X menjadi salah satu program favorit di hati masyarakat, terbukti hingga saat ini Mission X sudah bertahan sekitar 4 (empat) tahun menghiasi layar kaca masyarakat Indonesia. Hal tersebut tentunya tidak terlepas dari strategi kreatif yang dimiliki oleh Produser program Mission $\mathrm{X}$ dalam mempertahankan eksistensi program yang dijalankannya.

Dengan meningkatnya antusias masyarakat terhadap program Mission X TRANS TV, maka semakin besar pula tantangan yang dihadapi seorang Produser program tersebut dalam membuat ide atau gagasan kreatif yang akan diimplementasikan dalam program yang ditayangkan. Dalam menentukan sebuah stretegi kreatifpun, Produser tak hanya sekedar memberi keputusan, namun keputusan harus ditentukan secara matang dan sesuai dengan perkembangan zaman seperti sekarang ini. Hal lain yang menjadi tantangan bagi Produser yaitu penonton atau masyarakat yang kian hari semakin cerdas dalam memilih sebuah tayangan. Hal itulah yang menuntut seorang Produser untuk menciptakan atau

ISSN: 2355-0287, E-ISSN: 2549-3299 
mengembangkan sebuah strategi kreatif. Apabila Produser tidak mampu menghadapi tantangan tersebut, maka antusias masyarakat dan eksistensi program akan menurun.

\section{KAJIAN LITERATUR}

Kajian pustaka dan Kerangka Pemikiran merupakan panduan penulisan dalam aspek konseptual dan teoritis. Pada bagian ini akan dipaparkan mengenai konsep strategi kreatif produser, konsep komunikasi, serta teori-teori tentang Eksistensi program Mission X.

\section{Komunikasi}

Kehidupan manusia di dunia tidak dapat terlepas dari aktivitas komunikasi. Komunikasi merupakan bagian integral dari sistem dan tatanan kehidupan sosial manusia atau masyarakat. Menurut buku Pengantar Ilmu Komunikasi (Suprapto, 2011, p. 3) menyebutkan komunikasi sebagai suatu proses penyampaian pesan (berupa lambang, suara, gambar, dan lain-lain) dari sumber kepada sasaran (audience) dengan menggunakan saluran tertentu.

Dalam melakukan komunikasi, tentunya terdapat unsur-unsur yang mendukung keberhasilan terjadinya komunikasi. Dalam buku Sosiologi Komunikasi (Bungin, 2007, p. 71) menyebutkan beberapa unsur penting dalam komunikasi:

\section{Komunikator}

Pihak yang biasanya dalam bentuk organisasi/institusi formal yang dengan mengandalkan kecanggihan teknologi informasi dan media, ingin menyebarkan suatu informasi sehingga dapat ditangkap secara cepat oleh khalayak luas (massa).

2. Media Massa

Merupakan alat bantu atau wadah yang digunakan untuk menyebarkan informasi/pesan secara massal dari institusi pemilik media kepada khalayak/masyarakat yang massal.

3. Informasi (Pesan) Massa

Merupakan informasi yang telah dikemas dengan tujuan tertentu, diperuntukkan bagi masyarakat/khalayak secara massal.

4. Gatekeeper
Yaitu orang atau sekelompok yang bertugas menyeleksi, memperluas, dan atau membatasi informasi yang akan disampaikan kepada khalayak, dalam suatu organisasi media (misalnya redaksi, editor, jurnalis, dsb)

5. Khalayak (Publik)

Adalah massa yang menerima informasi massa yang disebarkan oleh media massa. Misalnya pendengar radio, atau pemirsa TV.

6. Umpan Balik

Merupakan respon yang timbul dari khalayak akibat informasi massa yang disampaikan oleh organisasi media. Umpan balik dalam komunikasi massa tidak seperti komunikasi langsung. Umpan balik dalam komunikasi massa bersifat tertunda atau tidak segera/tidak langsung.

Berdasarkan penjelasan di atas, peneliti memahami bahwa keberhasilan dari proses penyampaian pesan kepada penerima tentunya didukung oleh beberapa unsur yang saling berkaitan.

\section{Komunikasi Organisasi}

Menurut Deddy Mulyana dalam buku Ilmu Komunikasi Suatu Pengantar (2007:83) mengatakan bahwa komunikasi organisasi terjadi dalam suatu organisasi, bersifat formal dan juga informal, dan berlangsung dalam jaringan yang lebih besar daripada komunikasi kelompok. Oleh karena itu, organisasi dapat diartikan sebagai kelompok dari kelompok-kelompok.

Komunikasi dalam organisasi khususnya mempunyai hubungan dengan satu atau lebih dimensi-dimensi struktur organisasi (misalnya peranan, status, kompleksitas teknologi, pola-pola oboritas, dan sebagainya (Suprapto, 2007, p. 105).

\section{Komunikasi Massa}

Menurut Jay Black dan Federick C. Whitney (1988) dalam buku (Nurudin, 2011, p. 12) disebutkan, "Mass communication is a process whereby mess-produced message are transmitteg to large, anonymous, and heterogeneous masses of receivers (Komunikasi massa adalah sebuah proses dimana pesan- 
pesan yang diproduksi secara massal/tidak sedikit itu disebarkan kepada massa penerima pesan yang luas, anonim, dan heterogen)".

Komunikasi massa mempunyai ciri-ciri khusus (Suprapto, 2011, pp. 19-20) sebagai berikut:

1.

satu arah.

Berlangsung

Dalam komunikasi massa feed back baru akan diperoleh setelah komunikasi berlangsung.

2. Komunikator

pada komunikasi massa melembaga. Informasi yang disampaikan melalui media massa merupakan produk bersama. Seorang komunikator dalam media massa bertindak atas nama lembaga dan nyaris tidak memiliki kebebasan individual. Karena pesan-pesan yang disebarkan melalui media massa merupakan hasil kerja sama (collective).

3. bersifat umum.

Pesan-pesan

Pesan-pesan yang disampaikan melalui media massa pada umumnya bersifat umum (untuk orang banyak).

4.

keserempakan.

Melahirkan

Dalam komunikasi massa ada keserempakan dalam proses penyebaran pesan-pesannya. Serempak berarti khalayak bisa menikmati media massa tersebut hampir bersamaan.

5.

Komunikan
komunikasi massa bersifat heterogen. Audiens komunikasi massa mempunyai latar belakang, profesi dan usia yang berbeda.

Fungsi komunikasi massa menurut Jay Black dan Frederick C. Whitney (1988) dalam buku (Nurudin, 2011, p. 64) antara lain:

1. To inform (menginformasikan)

Fungsi informasi merupakan fungsi paling penting yang terdapat dalam komunikasi massa. Komponen paling penting untuk mengetahui fungsi informasi adalah berita-berita yang disajikan.

2. To entertain (memberi hiburan) Fungsi hiburan untuk media elektronik menduduki posisi yang paling tinggi dibandingkan dengan fungsi lain. Masyarakat menjadikan televisi sebagai media hiburan.

3. To persuase (membujuk)

Media massa juga mampu menggerakkan seseorang untuk berbuat sesuatu hal dan tidak berbuat hal lain, misalnya dalam iklan.

4. Transmission of the culture (transmisi budaya)

Transmisi budaya merupakan salah satu fungsi komunikasi massa yang paling luas. Transmisi budaya tidak dapat dielakkan dan selalu hadir dalam berbagai bentuk komunikasi yang mempunyai dampak pada penerimaan individu.

\section{Strategi Kreatif}

Strategi kreatif merupakan dua kata berbeda yang terdiri dari kata strategi dan kreatif. Strategi Penyiaran menurut (Morissan, 2009, p. 136) dalam buku Manajemen Media adalah program umum untuk pencapaian tujuan-tujuan organisasi dalam pelaksanaan misi. Kata "program" dalam definisi tersebut menyangkut suatu peranan aktif, sadar dan rasional yang dimainkan oleh manager dalam perumusan strategi organisasi.

Strategi memberikan pengarahan terpadu bagi organisasi dan berbagai tujuan organisasi, dan memberikan pedoman pemanfaatan sumber daya organisasi yang digunakan untuk mencapai tujuan.

Dalam buku Manajemen Media Penyiaran (Morissan, 2009, p. 248) strategi yang diperlukan dibidang media penyiaran yaitu:

a. Berfikir seperti pemirsa. Tanpa adanya pemirsa yang mengikuti siaran maka pengelola media penyiaran tidak akan pernah berhasil untuk menarik peminat.

b. Pengelola media penyiaran harus menganggap waktu siaran bernilai penting setiap detiknya dan harus menggunakan detik siaran itu dengan mendayagunakan kemampuan dalam menjangkau pemirsa.

c. Pegelola media penyiaran berkompetisi untuk merebut waktu 
orang lain agar mau menyaksikan acara yang disuguhkan. Oleh karena itu, pengelola media penyiaran harus bisa membuat atau memproduksi program-program acara yang mampu menarik minat pemirsa.

Jika dikaitkan dengan masalah penjelasan di atas, maka strategi yang dimaksud adalah suatu perencanaan kreatif yang dilakukan oleh seorang Produser dalam mempertahankan eksistensi program Mission X. Kunci sukses dari setiap program televisi terletak pada perencanaan dan sikap kreatif. Hal tersebut menjadi faktor yang paling penting dalam memproduksi program televisi.

Dalam buku Teknik Produksi Program Televisi (Wibowo, 2007, p. 21) ada 13 elemen strategi kreatif dalam produksi acara, yaitu:

a. Target Penonton

Sebelum merencanakan suatu program, seorang Produser perlu mengkaji secara teliti tentang target penonton, yaitu segmen audiens/penonton yang menjadi sasaran program.

b. Bahasa Naskah

Naskah merupakan penjabaran ide dalam huruf-huruf atau bahan-bahan berita yang siap untuk diset. Bahasa naskah terkait dengan kata-kata yang digunakan dalam naskah, baik drama maupun nondrama.

c. Format Acara

Format acara televisi adalah sebuah perencanaan dasar dari suatu konsep acara yang akan menjadi alasan kreativitas dan desain produksi yang akan terbagi dalam berbagai kriteria utama yang disesuaikan dengan tujuan target pemirsa acara tersebut.

d. Punching Line

Punching Line adalah kejutankejutan dalam dialog naskah dimainkan oleh para pemain yang sengaja dituliskan untuk menghentak perhatian penonton yang mulai jenuh dan bosan. Kejutan naskah dapat berupa komedi, celetukan, pertanyaan, tangisan, dan ungkapan peribahasa.

e. Gimmick and Funfare

Gimmick adalah trik-trik yang digunakan untuk mendapatkan perhatian penonton dalam bentuk sound effect, music ilustrasi, adegan suspense (tegang), mimik, ekspresi dan akting pemain.

f. Clip Hanger

Clip hanger adalah sebuah scene atau shot yang ditambahkan karena adegan terpaksa dihentikan oleh commercial break (iklan). Clip hanger digunakan untuk membuat penonton penasaran pada apa yang akan terjadi selanjutnya sehingga penonton tidak pindah ke lain channel.

g. Time and Bumper

Opening time merupakan identitas pembuka acara dengan durasi 30 detik sampai 2,5 menit. Bumper adalah identitas perantara acara dengan durasi 5 detik. Penggunaan bumper harus dibuat semenarik mungkin karena selalu diputar ulang setiap memulai ataupun mengakhiri tayangan dan paling sering dihafal oleh pemirsa.

h. Penata Artistik

Penata artistik disebut juga tata panggung pada suatu program juga menjadi identitas program. Tata artistik untuk setiap program tidak sama, hal ini karena tata artistik disesuaikan dengan refrensi acara yang di produksi. Selain itu penataan artistik juga menjadi panduan bagi kameramen dalam menentukan blocking pengambilan gambar.

i. Music and Fashion

Selain isi program, penonton juga senang memperhatikan wardrobe dan make up pengisi acara, juga musik yang menjadi ilustrasi program.

j. Ritme dan Birama Acara

Ibarat sebuah lagu, acara televisi mempunyai Intro Refrain Coda dan Improvisasi yang dibungkus dalam sebuah aransemen musik. Sehingga dalam naskah drama maupun nondrama, setiap ketuk birama dan ritme acara dari awal hingga akhir harus sudah diperhitungkan, hal ini untuk menghindari kejenuhan penonton.

k. Logo dan Music Track untuk ID Tune

Sebuah program acara televisi harus mempunyai logo dan music track 
(music untuk identitas acara) yang familiar bagi penonton. Logo acara yang baik adalah yang mudah diingat, dan music track yang baik adalah yang enak untuk dinikmati.

1. General Rehearsel (GR)

Yaitu latihan yang dilakukan sebelum syuting berlangsung. Hal ini dilakukan untuk meminimalisir kesalahan yang mungkin terjadi ketika produksi. Yang menjadi perhatian ketika GR yaitu camera blocking, tata lampu, dan tata suara.

m. Interactive Program

Yaitu suatu percakapan atau interaksi timbal balik dengan pemirsa di rumah. Selain digunakan untuk mengetahui minat pemirsa terhadap suatu tayangan, interaktif dengan pemirsa juga bermanfaat untuk pengembangan ide-ide kreatif acara selanjutnya. Dengan adanya interaktif dengan pemirsa, pemirsa akan merasa dilibatkan dan semakin tertarik pada program bersangkutan.

\section{METODE PENELITIAN}

Metode yang peneliti gunakan pada penelitian ini adalah deskriptif. Penelitian desktiptif adalah sebuah penelitian yang bertujuan untuk memberikan atau menjabarkan suatu keadaan atau fenomena yang terjadi saat ini dengan menggunakan prosedur ilmiah untuk menjawab masalah secara aktual, (Sugiyono, 2011, p. 29).

Pendekatan deskriptif menurut (Moleong, 2013, p. 102), yaitu data-data yang dikumpulkan berupa kata-kata, gambar, dan bukan angka-angka sehingga laporan penelitian akan berisi kutipan-kutipan data untuk memberikan gambaran penyajian laporan tersebut.

Penelitian kualitatif adalah penelitian yang digunakan untuk meneliti pada kondisi objek alamiah dimana peneliti merupakan instrumen kunci, (Gunawan, 2013, p. 81).

Menurut (Gunawan, 2013, p. 82) mengutip Borgan dan Tayandar, Pendekatan kualitatif adalah prosedur penelitian yang menghasilkan data deskriptif berupa kata-kata yang diarahkan pada latar dan individu secara holistik (utuh).
Dari penjelasan di atas, peneliti memahami bahwa penelitian kualitatif merupakan penelitian yang terbentuk dari fenomena-fenomena sosial yang diamati dan dianalisis dengan menceritakan atau menjelaskan dengan kata-kata atau kalimat. Data dalam penelitian menggunakan pendekatan kualitatif didapatkan dengan melakukan wawancara mendalam, dokumentasi dan arsip.

Dalam penelitian ini, peneliti menggunakan pendekatan kualitatif karena peneliti mendapatkan data dan informasi melalui observasi secara langsung, wawancara mendalam, dokumentasi serta arsip yang dapat menjawab mengenai strategi kreatif Produser dalam mempertahankan eksistensi program Mission $\mathrm{X}$ pada stasiun televisi Trans TV.

\section{Key Informan dan Informan Penelitian}

Key informan adalah mereka yang tidak hanya bisa memberi keterangan tentang sesuatu kepada peneliti, tetapi juga bisa memberi saran tentang sumber bukti yang mendukung serta menciptakan sesuatu terhadap sumber yang bersangkutan, (Moleong, 2013, p. 3).

Sedangkan informan ialah orang pada latar penelitian yang dimanfaatkan untuk memberikan informasi tentang situasi dan kondisi latar penelitian, (Moleong, 2013, p. 132).

Dalam penelitian ini, peneliti menentukan key informan dan informan yang sesuai dan mampu memberikan informasi tepat dan relevan dengan permasalahan yang diteliti, antara lain:

Peneliti menentukan key informan yang relevan agar mudah mendapatkan informasi yang tepat dalam penelitian ini yakni Rosul Hidayatullah selaku Produser program Mission X.

Informan dalam penelitian ini adalah beberapa crew yang bertugas dalam program Mission $X$ yang memiliki informasi relevan terkait dengan 
permasalahan yang diteliti. Crew yang terlibat yaitu, Reynaldo selaku Ass.Produser, dan Ratih selaku Creative.

\section{Metode Pengumpulan Data}

Penelitian kualitatif dengan jenis penelitian deskriptif melalui berbagai tahapan. Pada penelitian ini, dalam pengumpulan data yang diinginkan, penulis menggunakan metode wawancara, dokumentasi, dan studi kepustakaan.

\section{PEMBAHASAN}

Pada bagian ini peneliti memaparkan hasil penelitian dan analisis data yang dilakukan peneliti. Analisis data bersumber dari transkrip hasil wawancara mendalam dengan key informan dan informan serta observasi lapangan yang telah dilakukan peneliti.

Data yang peneliti dapatkan dalam penelitian ini adalah data primer dan sekunder. Adapun data primer, peneliti dapatkan dari hasil wawancara dan observasi, sedangkan data sekunder berasal dari dokumentasi, arsip dan bahan-bahan lain yang diperlukan.

Pihak-pihak yang telah berhasil peneliti wawancarai yaitu Rosul Hidayatulandah yang biasa dipanggil Kang Ocul selaku Produser program Mission X TRANS TV, Reynaldo Faulana selaku Asisten Produser dan Ratih Marbun selaku Kreatif. Peneliti memaparkan hasil penelitian mengenai strategi kreatif Produser dalam mempertahankan program Mission $X$ pada Stasiun Televisi TRANS TV sebagai berikut:

\section{Tugas Produser TRANSTV}

Dalam mencapai sebuah tujuan perusahaan tentunya tidak terlepas dari kemampuan yang dimiliki oleh sumber daya manusia (SDM) dan sarana atau fasilitas yang mendukung. Kemampuan yang diaplikasikan oleh SDM juga harus dapat menciptakan sebuah hasil yang dapt diterima oleh banyak pihak. Dalam hal ini, TRANS TV memiliki Produser sebagai pemangku program atau yang bertanggung jawab atas sebuah program. Hal ini sesuai dengan pernyataan para ahli salah satunya dalam Buku Manajemen Media Penyiaran (Morissan, 2009, pp. 274-275), sebagai berikut:

"Produser adalah orang yang bertanggung jawab mengubah atau menciptkan ide/gagasan kreatif ke dalam konsep yang praktis dan dapat diterima dihati khalayak luas. Produser harus memastikan adanya dukungan keuangan bagi terlaksananya produksi program TV serta mampu mengelola keseluruhan proses produksi termasuk melaksanakan penjadwalan."

Posisi Produser memiliki peran penting dalam menajalankan sebuah program. Adapun tugas Produser TRANS TV yaitu bertanggung jawab penuh sebelum program terlaksana hingga program terselesaikan. Hal ini seperti dikemukakan oleh Kang Ocul selaku Produser program Mission X:

"Tugas utama Produser itu adalah sebagai pemangku program atau yang bertanggung jawab penuh atas programnya disitu melibatkan hal2 mulai dari managerial, budget, konten kreatif dan juga bertangung jawab di ranah mulai pra produksi, produksi sampe pasca produksi."

Kang Ocul juga menambahkan mengenai uraian tentang tugas seorang yang dilakukan produser, seperti yang dikemukakan berikut ini:

"Kreatif menggali ide sampein ke Saya, Saya kasih arahan dan Saya kasih batasan. Kita bikin diskusi konten dan kemudian kita eksekusi ide tersebut."

Reynaldo selaku Asisten Produser mengemukakan pendapatnya mengenai tugas Produser, yaitu sebagai berikut:

"Nah tugas Produser itu ada banyak nih, dari mulai pra produksi, produksi 
sampai pasca produksi. Untuk pra produksinya, biasanya si Kang Ocul atau Produser kita itu mempersiapkan atau anggarin budget untuk shooting terus mikirin konten apa yang pas untuk dijadiin isi pada saat produksi, selain itu juga Kang Ocul nyari artis tamu nih buat jadi temen agen kita."

Kemudian Reynaldo menambahkan mengenai uraian tugas seorang Produser sebagai berikut:

"Untuk produksinya tugas kita itu bertanggung jawab atas berjalannya proses shooting kita. Memastikan apakah proses tersebut berjalan lancar sampai makan para crew dan artispun menjadi tanggung jawab kita dan tanggung jawab Produser pada saat pasca produksi adalah mulai dari selesai shooting sampai program tersebut di tayangkan ke televisi.

Biasanya kalau habis selesai shooting kita pasti selalu mengadakan briefing bareng tim. Buat tau apa kendala ataupun masalah yang dihadapi pada saat proses shooting tadi. Gunanya agar kesalahan itu bisa langsung diperbaiki dan kendala bisa dibenahi jadi gak mengganggu proses shooting selanjutnya."

Berdasarkan temuan peneliti tugas seorang Produser tak hanya bertanggung jawab terhadap berlangsungnya program yang dijalankan, melainkan juga mengelola budget atau financial yang dibutuhkan untuk program yang dijalankan. Hal ini seperti pernyataan yang diutarakan oleh Kang Ocul:

"Nah selain bertanggung jawab atas konten, tugas Saya juga menyusun budget. Jadi sebelum produksi pertama Produser akan selalu mengajukan budget. Jadi kita menyusun budget dengan plafon yang sudah ditentukan oleh perusahaan untuk program. Saya nyusun budget seefektif mungkin, bagaimana konten Saya terseleggara dengan baik tapi budget Saya gak over."

Dalam menjalankan tugasnya seorang Produser juga menganggap penting sebuah proses komunikasi. Hal tersebut disampaikan seperti berikut ini:

"Menurut Saya gak ada superman tapi yang ada itu supertim. Ketika Saya punya tim sekecil apapun tim Saya atau sebesar apapun tim Saya, sebisa mungkin Saya akan berkomunikasi dengan tim Saya. Karena dengan adanya komunikasi yang baik di tim Saya, justru mempermudah Saya dalam urusan diskusi soal program Saya."

Hal tersebut juga serupa dengan pendapat Reynaldo mengenai kegiatan berkomunikasi sebagai berikut:

"Saya bener-bener ngejaga banget yang namanya berkomunikasi sama mereka. Karena, kalo Sayanya atau tim Saya gak akur dengan temen2 yang lain, otomatis bakal mengganggu kesuksesan program ini kan."

Reynaldo juga menambahkan mengenai pentingnya berkomunikasi yaitu seperti yang diungkapkan sebagai berikut:

"Nah kalo Saya, cara Saya berkomunikasi bahkan mengajarkan mereka berkomunikasi itu dengan cara diskusi. Diskusi ngebahas soal program, bahkan ngebahas hal lain hanya untuk sekedar intermezzo aja.

Walaupun di program Saya sebagai Ass.Prod, tapi Saya gak menjadikan tim dibawah Saya itu takut ke Saya. Justru Saya merangkul mereka untuk "yuk sama2 kita kerja bareng, partner bareng, diskusi bareng" karena Saya gak mau tim Saya itu jadi tertutup, Saya pengen tim Saya terbuka dalam segala hal khususnya tentang program. Jadi Saya mengajarkan tim untuk apapun masalah, apapun kendala, apapun ide itu Saya minta untuk di share. Karena gak menutup kemungkinan justru ide tim 
Saya lah yang lebih bagus daripada ide yang Saya punya."

Dari pemaparan di atas peneliti menilai bahwa tugas Produser tak hanya bertanggung jawab pada proses menciptakan sebuah ide/gagasan dalam program yang dijalankan, namun juga harus mampu menjalankan seluruh proses dengan baik termasuk proses berkomunikasi dengan tim dikarenakan proses komunikasi juga mempengaruhi pekerjaan atau tugas yang dijalankan dan proses budgeting juga harus dikelola secara terorganisir demi berjalannya sebuah program.

Selain itu Produser juga melakukan sebuah evaluasi kerja guna meningkatkan kualitas kerja dan juga untuk mengoreksi hal-hal apa saja yang harus diperbaiki.

Hal yang disampaikan oleh Kang Ocul senada dengan pendapat salah satu Ahli yang menjelaskan mengenai 13 elemen strategi kreatif dalam produksi acara, yaitu :
a. Target Penonton
b. Bahasa Naskah
c. Format Acara
d. Punching Line
e. Gimmick and Funfare
f. Clip Hanger
g. Time and Bumper
h. Penata Artistik
i. Music and Fashion
j. Ritme dan Birama Acara
k. Logo dan Music Track untuk ID Tune
1. General Rehearsel (GR)
$\mathrm{m}$. Interactive Program

Reynaldo juga memberikan pendapat mengenai pengaruh strategi kreatif terhadap eksistensi program, seperti berikut ini:

"Strategi kreatif sangat amat mempengaruhi eksistensi program lah, kalo kita gak punya ide-ide kreatif atau ide kita cuma nyontek orang, berarti gak punya strategi dan gak kreatif."

Dari pernyataan di atas, peneliti menyimpulkan bahwa untuk menjalankan strategi kreatif Produser harus bijak dalam memutuskan ide-ide kreatif yang akan diimplementasikan dan mengacu pada beberapa elemen strategi kreatif.

\section{Strategi Kreatif Produser Program Mission X TRANSTV}

Berhasil atau tidaknya suatu program juga didukung oleh strategi yang diapliksikan oleh sekeandampok orang dalam menjalankan tugasnya. Strategi yang dijalankanpun tidak hanya sebuah strategi yang ditentukan oleh satu pihak dan diperoleh dalam sekejap. Namun strategi yang diperoleh berdasarkan hasil pemikiran bersama-sama walaupun pada akhirnya diputuskan oleh satu pihak atau pimpinan.

Dalam program Mission X dibutuhkan strategi kreatif guna mempertahankan eksistensi program. Strategi kreatif yang dibutuhkan yaitu sebuah ide, rancangan atau siasat yang diciptakan berbeda dari program lainnya. Hal ini seperti yang diungkapkan oleh Kang Ocul sebagai berikut:

"Strategi kreatif dalam suatu program menurut Saya adalah rencana kreatif atau ide2 kreatif yang kita buat atau kita create untuk dapat menghasilkan ide baru atau penemuan baru yang orang lain atau TV lain belum pernah dapatkan atau temukan. Nah dalam program, strategi kreatifnya itu adalah ide yang kita lahirkan menjadi sebuah konten atau isi dari acara tersebut.kreatifitas seorang Produser tentunya didukung dengan timnya yaitu kreatif. Bagaimana tugas seorang Produser untuk mengembangkan ide kreatif dari temen2 kreatif, itu juga masuk kedalam strategi kreatifnya Produser tuh. Strategi kreatif 
memang sangat mempengaruhi sebuah program."

Pernyataan mengenai strategi kreatifpun dipertegas oleh Ratih selaku Kreatif yang menyampaikan pernyataannya sebagai berikut:

"Menurut Saya Produser harus pinterpinter nentuin ide2 yang sudah kita buat. Karena gak gampang buat Produser memutuskan ide-ide mana saja yang harus diimplementasikan. Supaya kita gak kalah saing dengan program lainnya. Satu hal lagi menurut Saya penentuan artis itu penting soalnya mereka sangat berpengaruh terhadap minat penonton."

Keberhasilan setiap program terletak pada perencanaan yang baik dan ide yang kreatif. Hal tersebut juga salah satu faktor Produser dalam mengambil keputusan sebuah strategi. Acuan-acuan yang dijadikan Produser dalam mengambil keputusan strategi, diantaranya seperti ungkapan yang dikemukakan oleh Kang Ocul:

"Saya jelasin yang Saya inget aja yaa. Point penting menjadi landasan kita dalam menentukan strategi kreatif itu yang

pertama target: kita nentuin siapa target penonton yang akan kita tuju, target itu mencangkup usia, jenis kelamin dan juga status sosial. Nah di Mission X ini karena target penontonnya semua umur jadi siapapun dari usia berapapun, dari jenis kelamin apapun dan kalangan manapun bisa nonton Mission X ini.

Yang kedua, bahasa naskah: bahasa naskah itu biasanya digunakan sama artis kita atau agen Mission X, merekapun gak sembarangan ngomong Pak Uta. Sebelum mulai kita selalu briefing temen-temen artis untuk kasih tau mereka batasan-batasannya. Karena kita sangat menghindari ada kata-kata yang tidak pantas didengar.
Yang ketiga, format acara: nah format acara ini bisa dibilang sebagai konten. Dasar dari suatu konsep yang akan diaplikasikan pada saat proses produksi. Disini kreatifitas dan bagaimana cara kita mengkemas program diuji, karena merupakan menjadi tolak ukur keberhasilan program kita.

Keempat, punching line: punching line itu kaya apa ya contohnya kaya celetukanlah, atau komedi mendadak yang biasanya dilakukan sama agen kita. Misalkan kaya agen Aden, Aming dan Melky, itu mereka yang paling sering punching line. Biasa punching line itu mengundang penonton untuk ketawa sih, karena kadang celetukan yang garing yang justru bisa menghibur penonton.

Kelima, Gimmick: gimmick itu apa yaa semacam trik untuk mencari perhatian dari penonton. Biasanya sih dalam bentuk adegan, mimik, ekspresi para pemain. Di Mission X biasa yang sering buat gimmick itu agen Isa, yang suka pura-pura berantem sama agen Aming.

Keenam, penata artistik: biasa disebut dengan penata panggung, kaanda kita gak gak pake panggung yaa panggungnya kita ya seluruh andakasi itu. Karena para agennya moving terus kan gak Cuma stuck di satu tempat.

Ketujuh, musik dan fashion. Yang seperti Pak Uta tau, Mission X kan punya musik atau jingle tersendiri kan, boleh Pak Uta cek lagi di youtube. Dan untuk wadrobenya sendiri, di Mission X kan terbagi menjadi 2 tim, yaitu tim merah dan tim biru. Nah untuk kostumnya tim merah pastinya dengan kaos berwarna merah Mission $\mathrm{X}$ bertuliskan nama agen begitupun dengan tim biru. Jadi gak akan ketuker tuh yang mana kawan dan lawan saat permainan berlangsung.

Kedelapan, Andago dan Musik: program Mission X mempunyai andago tersendiri, bisa Pak Uta liat setiap awal 
tayangan dimulai, dan untuk musiknya, tim selalu menggunakan musik yang sedang ngehits, jadi penonton juga gak bosen untuk menonton karena didukung dengan backsound dengan lagu yang easy listening."

\section{Eksistensi Program Mission X TRANSTV}

Program Mission X yang sudah mengudara kurang lebih empat tahun mampu membuktikan kepada khalayak luas bahwa game show yang memiliki keunikan dan perbedaan dari game show lainnya dapat diterima di hati masyarakat luas. Hal tersebut tak luput dari kerja keras dan kerja sama tim yang kuat dan memiliki kemampuan yang teruji.

Eksistensi tayangan Mission X dapat bertahan karena setiap tim mulai dari produser hingga crew mampu menjalankan strategi yang sudah ditentukan oleh Produser. Strategi yang tepat dapat mempengaruhi keberhasilan sebuah program. Berhasil atau tidaknya sebuah program dapat dilihat dari eksistensi program itu sendiri.

Reynaldo selaku Asisten Produser menyampaikan pendapatnya mengenai eksistensi program Mission X seperti berikut ini:

"Menurut Saya yang utama sih kita harus selalu berinovasi sesuai tuntutan zaman. Soalnya sekarang-sekarang ini penonton makin cerdas dalam menentukan pilihan tayangan. Jadi kita harus mampu mengembangkan ide-ide kreatif. Terus kiat-kiat lainnya kita harus tau kelemahan pesaing atau programprogram serupa kaya kita. Dari situ kita jadi tau apa aja yang kurang dari program kita dan apa aja yang unggul dari program kita, dan keunggulan program kita itu yang menjadikan kiat utama kita untuk tetap mempertahankan eksistensi kita. Yang terakhir selalu menjaga hubungan baik sama pihak internal maupun eksternal."
Sedangkan Ratih mengemukakan pandangannya mengenai eksistensi Program Mission X seperti berikut ini:

"Kalo menurut Saya, kiat-kiatnya si Produser terus memperbarui ide-ide atau berinovasi terhadap hal-hal baru. Menyesesuaikan sama perkembangan jaman jadi biar gak ketinggalan jaman. Terus si Produser juga harus berbaur dengan tim, gak hanya dengan tim kreatif aja tapi juga sama tim yang lain supaya Produser memahami apa kendala yang kita hadapi dan saling tukar pikiran terlebih mengenai program."

Dari pernyataan di atas, peneliti menilai bahwa eksistensi sebuah program dapat berhasil apabila strategi atau ide yang dijalankan memiliki inovasi agar dapat diterima oleh khalayak luas. Dalam program Mission X strategi yang dijalankan harus mampu bersaing dan sudah tersusun dengan sedemikian baik. Selain itu harus bisa memahami apa kelemahan lawan dan mengetahui apa keunggulan program yang dijalankan.

Peneliti menilai kunci utama sebuah keberhasilan dalam menjalankan pekerjaan adalah komunikasi yang terjalin dengan baik. Menurut peneliti Produser program Mission X sudah mengaplikasikan strategi kreatif dengan tepat dan eksistensi program Mission X dapat bertahan dikarenakan adanya strategi kreatif yang selalu berinovasi dan komunikasi yang sudah terjalin dengan baik.

\section{PENUTUP}

\section{Simpulan}

Berdasarkan hasil penelitian yang dilakukan peneliti di PT. Televisi Transformasi Indonesia pada Produser program Mission, dengan judul Strategi Kreatif Produser Dalam Mempertahankan Eksistensi Program Mission X Pada Stasiun Televisi TRANS TV, maka pada bab ini peneliti memaparkan kesimpulan dan saran sebagai jawaban terhadap masalah dalam penelitian ini bahwa: 
1. Kunci utama sebuah keberhasilan dalam menjalankan pekerjaan adalah komunikasi yang terjalin dengan baik. Bagi Produser dan tim, komunikasi merupakan hal yang mempengaruhi keberhasilan dalam tim.

2. Seorang Produser dalam menentukan strategi kreatif program Mission X berlandaskan pada elemen-elemen sebagai berikut: target penonton, bahasa naskah, format acara, punching line, gimmick and funfare, clip hanger, time and bumper, penata artistik, music and fashion, ritme dan birama acara, logo dan music track untuk ID tune, general rehearsel (GR), dan interactive program.

3. Hal tersebut merupakan salah satu upaya untuk mempertahankan eksistensi program Mission X.

4. Selalu menggali ide-ide baru dan mampu mengembangkan ide-ide kreatif.

\section{Saran}

1. Dalam proses berkomunikasi, baiknua satu sama lain dapat mengetahui kendala apa saja yang dihadapi dan mengetahui caracara untuk mempertahankan eksistensi sebuah program yang dijalankan.

2. Eksistensi program Mission $\mathrm{X}$ dapat bertahan dikarenakan adanya strategi kreatif yang selalu berinovasi dan komunikasi yang sudah terjalin dengan baik.

3. Diharapkan agar komunikasi satu sama lain tetap terjaga.

4. Produser beserta tim harus mampu dan bisa menyesuaikan dengan perkembangan zaman serta minat masyarakat, karena saat ini penonton atau penikmat tayangan program televisi semakin cerdas dalam menentukan sebuah tayangan yang akan ditonton.

\section{REFERENSI}

Bungin, B. (2007). Sosiologi Komunikasi. Jakarta: Kencana Prenada Media Group.

Gunawan, I. (2013). Metode Penulisan Kualitatif: Teori dan Praktik. Jakarta: Bumi Aksara.

Moleong, L. J. (2013). Metode Penelitian Kualitatif. Bandung: Remaja Rosdakarya.

Morissan. (2009). Manajemen Media Penyiaran: Strategi Mengelola Radio \& Televisi. Jakarta: Kencana.

Nurudin. (2011). Pengantar Komunikasi Massa (4th ed.). Jakarta: Rajawali Pers.

Sugiyono. (2011). Metode Penelitian Kuantitatif, Kualitatif, dan $R \& D$. Bandung: Alfabeta.

Suprapto, T. (2007). Berkarir Di Bidang Broadcasting. Yogyakarta: Media Pressindo.

Suprapto, T. (2011). Pengantar Ilmu Komunikasi. Jakarta: Buku Seru.

Wibowo, F. (2007). Teknik Produksi Program Televisi. Jakarta: Pinus Book Publisher.

\section{DATA DIRI PENULIS}

Murtiadi, S.I.Kom, M.I.Kom. Lahir di Jakarta, 10 September 1986. Lulus S1 dari FIKOM jurusan Public Relations di Univ Persada Indonesia Y.A.I, Jakarta; S2 pada Prodi Magister Ilmu Komunikasi di Pascasarjana Univ Mercu Buana, Jakarta; dan Sedang Menempuh Kuliah S3 Program Doktoral Ilmu Komunikasi Univ Sahid Jakarta.

Pernah menjadi Supervisor di Fun World, CSO Bank Mandiri (2007-2009), 
Dosen D3 AKOM BSI, Staf PUDIR 3

Bidang Kemahasiswaan di BSI Jakarta (2011) dan Public Relations Manager di TVONE (2010-2015). Kini menjadi Praktisi Government Public Relations
(Tenaga Humas Pemerintah) Kemenkominfo yang di tempatkan pada Kemenkes RI dan Kemenag RI, sekaligus, S1 Fikom IBIK 57, S1 STIKOM Prosia. 